\title{
Effect of Tillage Practices and Rice Straw Management on Soil Environment and Carbon Dioxide Emission
}

\author{
M.M. Rahman ${ }^{1}$, J.C. Biswas ${ }^{2}$, M. Maniruzzaman², A.K. Choudhury ${ }^{3}$ and F. Ahmed ${ }^{3}$ \\ ${ }^{1}$ Bangabandhu Sheikh Mujibur Rahman Agricultural University, Gazipur 1706, Bangladesh \\ ${ }^{2}$ Bangladesh Rice Research Institute, Gazipur 1701, Bangladesh \\ ${ }^{3}$ Bangladesh Agricultural Research Institute, Gazipur 1701, Bangladesh \\ *Corresponding author and Email: mizan@bsmrau.edu.bd
}

Received: 12 March $2017 \quad$ Accepted: 12 June 2017

\begin{abstract}
Carbon (C) inputs and tillage intensity impinge on $\mathrm{C}$ degradation and thus $\mathrm{CO}_{2}$ emission and soil properties get influenced. Information on $\mathrm{CO}_{2}$ emission and soil properties under different tillage practices and straw application in rice based cropping system in Bangladesh is lacking. The effects of rice straw and tillage operations on $\mathrm{CO}_{2}$ emission and soil properties were quantified in four consecutive seasons of transplanted Aman and Boro rice grown under two tillage operations (minimum and traditional) and three levels of rice straw (control, incorporation and mulch) during 2010 to 2012. Irrespective of tillage practices, $\mathrm{CO}_{2}$ emission peak reached after 3-4 weeks of straw application. Carbon dioxide emission ranged from 26 to $59 \mathrm{~kg} \mathrm{ha}^{-1}$ day $^{-1}$ under minimum tillage and 25 to $96 \mathrm{~kg} \mathrm{ha}^{-}$ ${ }^{1}$ day $^{-1}$ under traditional tillage. Minimum tillage accumulated more $\mathrm{C}$ in soil, which could be attributed to lower rates of emission and straw degradation. Carbon degradation rate constants, $\mathrm{k}$ were 0.000300 and $0.000394\left(\right.$ day $\left.^{-1}\right)$ under minimum and traditional tillage, respectively. Small increment in soil C might help reducing $\mathrm{CO}_{2}$ in the atmosphere. Mineralization of straw increased nutrient contents and thereby improved the soil fertility and availability to the crops for nutrients' uptake. Traditional tillage significantly reduced soil bulk density and increased field capacity of the soil, whereas in addition, rice straw application furthermore increased permanent wilting point and available water content in the soil. The present study may help in identifying suitable tillage and residue management options in reducing $\mathrm{CO}_{2}$ emission from rice fields.
\end{abstract}

Keywords: $\mathrm{CO}_{2}$ emission; tillage; rice straw; field capacity; permanent wilting point.

\section{Introduction}

Global warming due to climate change appeared as a great concern, which may continue beyond decades resulting in dangerous consequences for many countries in the world. This negatively affects agriculture, living being and finally the total environment. Carbon dioxide and methane are the most important greenhouse gases releasing from paddy fields responsible for global warming (Lee et al., 2006; Munoz et al., 2010). World soils and terrestrial ecosystems 
have been a source of atmospheric $\mathrm{CO}_{2}$. Reducing $\mathrm{CO}_{2}$ emission from rice fields through carbon build up in soil is of prime importance (Rahman 2013a). The amount of $\mathrm{CO}_{2}$ emitted from croplands depends on types of crops/cropping systems, crops' residue management, soil and land management and climatic conditions.

Soil is a major source of emission for atmospheric $\mathrm{CO}_{2}$ content and reduction of its emission through $\mathrm{C}$ sequestration in soil is of prime importance as mitigation and adaptation strategies. Soil management practices like increasing soil OC, reduced tillage, manuring, residue incorporation, improving soil biodiversity, micro-aggregation and mulching can play an important role in accumulating carbon in the soil. It is generally assumed that after incorporation of residues to soils, it takes about one month for maximum microbial activities depending on $\mathrm{C}$ : $\mathrm{N}$ ratios of the provided organic materials. The higher is the carbon content, the longer time is needed to decompose it. The contribution of agricultural soils to $\mathrm{CO}_{2}$ emission depends on decomposition of different types of organic residues added to soil. Carbon dioxide is released through microbial and root respiration, where microflora contributes $99 \%$ of the $\mathrm{CO}_{2}$ arising as a result of decomposition of OM (Munoz et al., 2010).

Emission of $\mathrm{CO}_{2}$ results in lower reserves of $\mathrm{OM}$ in soils. Soil OM stabilizes soil structure and plays a central role in soil surface-atmosphere exchange of carbon. Globally, organic $\mathrm{C}$ in the upper $1 \mathrm{~m}$ of agricultural soil is about $167 \mathrm{Pg}$, and these soil have already lost 30 to $70 \%$ of their original soil C storage in the upper $30 \mathrm{~cm}$ due to changing land use systems, soil and crop management practices under a wide range of climatic conditions (Eve et al., 2002). Soils of Bangladesh have low reserves of carbon because of higher cropping intensity, higher decomposition rate of OM contributing to higher emission of $\mathrm{C}$, use of lesser quantity of organic manure and little or practically no use of green manures coupled with warmer temperature and high humidity. The rate of soil carbon emission is strongly regulated by the complex interaction among soil physical, chemical and biological processes and environmental conditions (Agehara and Warncke, 2005; Lee et al., 2006). Soil aerobic conditions produce $\mathrm{CO}_{2}$, while anaerobic conditions produce $\mathrm{CH}_{4}$, depending on the concentration of soil OC. Large quantities of OC added to soils through different manures and wastes to supply plant nutrients may significantly contribute to $\mathrm{CO}_{2}$ emission. However, proper management of organic materials, conservation tillage and mulching can play an important role in reducing $\mathrm{CO}_{2}$ emission and thus increase $\mathrm{C}$ build up in soil.

Carbon recycling to soils through different organic residues enhances carbon stock in soils (Rahman, 2013b), which depends upon several factors related to soil edaphic environment. Rice straws are important source for incorporation in the soils for improving soil physical, chemical and biological properties. However, it is considered to be the major source of $\mathrm{CO}_{2}$ emission from rice fields (Rahman, 2014). Different carbon inputs and tillage options affect organic matter degradation and thereby $\mathrm{CO}_{2}$ emission. Organic matter and nutrient deficiency appeared as major concerns in the intensively cultivated areas of Bangladesh. Because of hyperthermic temperature regime in the growing regions, organic matter mineralization is usually high, which is a concern of Bangladesh soil. Tillage is the most important practice having a major effect on $\mathrm{C}$ pool, either usually with illeffects under conventional ploughing or beneficial effects when conservation tillage is practiced (IPCC, 2000). Tillage has significant effect on soil health and subsequent crops' yields, while short-term effect of conservation or reduced tillage might not be noticeable in terms of soil characters. Conservation tillage practices can minimize rapid breakdown of plant residues and found that reducing tillage significantly decreases carbon loss, which results in the improved physical, chemical and biological properties of soil and thus improved crop productivity. The present carbon status in soils of 
Bangladesh is alarming and, therefore, proper and deliberate management of soil organic carbon has of great importance. Up to date information on $\mathrm{CO}_{2}$ emission and soil carbon and fertility build up are indispensible to combat global warming and climate change and for the sustainability of agricultural production systems (Rahman, 2010). However, such information under rice based cropping system in Bangladesh is scarce. Therefore, the objectives of this research were to quantify the effect of rice straw and tillage management in rice field on $\mathrm{CO}_{2}$ emission, carbon build up and physical and chemical properties of soils.

\section{Materials and Methods}

\subsection{Study site}

The experiment was conducted at the research farm of Bangabandhu Sheikh Mujibur Rahman Agricultural University, Gazipur, Bangladesh. The site is located at $24.09^{\circ} \mathrm{N}$ latitude and $90.25^{\circ} \mathrm{E}$ longitudes with an elevation of $8.2 \mathrm{~m}$ from sea level, which comes under the agroecological zone of Madhupur Tract. The soil belongs to Salna series and classified as Shallow Red Brown Terrace soil in Bangladesh classification and Inceptisols in USDA classification (Brammer, 1978), which is characterized by silty clay loam within $50 \mathrm{~cm}$ from the surface and is acidic in nature. The climate of the area is sub-tropical, wet and humid. Heavy rainfall occurs during June-July (269 to $370 \mathrm{~mm}$ ) and scanty rains during November to February (0 to $55 \mathrm{~mm}$ ).

Surface soil samples were collected, at the time of sowing and after harvest of the crop, air dried, grounded to pass through $2 \mathrm{~mm}$ sieve and subsequently used for analysis of $\mathrm{pH}$, total $\mathrm{N}$, available $\mathrm{P}, \mathrm{S}, \mathrm{Zn} \& \mathrm{~B}$ and exchangeable $\mathrm{K}$ following standard protocols (Page et al., 1982). For analysis of OC, a subsample was sieved through $0.2 \mathrm{~mm}$ sieve. The experimental field soil had low OC $(1.03 \%), \mathrm{N}(0.09 \%), \mathrm{K}(0.14$ meq $\left.100 \mathrm{~g}^{-1}\right), \mathrm{S}\left(6.5 \mathrm{mg} \mathrm{kg}^{-1}\right)$; very low $\mathrm{P}(2.4$ $\left.\mathrm{mg} \mathrm{kg}{ }^{-1}\right)$ and high $\mathrm{Zn}\left(2.32 \mathrm{mg} \mathrm{kg}^{-1}\right)$ content (BARC, 2005).

\subsection{Experimentation}

The study was conducted during August 2010 to May 2012 in four consecutive rice seasons of Transplanting aman (BRRI dhan49) and boro (BRRI dhan29) having two tillage operations (1) minimum tillage (MT) and (2) traditional tillage (TT) and three levels of rice straw management (1) control, (2) rice straw incorporation (RSI) and (3) rice straw mulch (RSM) in a factorial RCBD with four replications. The unit plot size was $4 \mathrm{~m} \times 3 \mathrm{~m}$ and each plot was separated by $30 \mathrm{~cm}$ wide well structured and polyethylene lined levee. The experimental field was prepared by country plough maintaining a depth of $15 \mathrm{~cm}$. The MT treatment received two passes of country plough while the TT treatment received 4 passes. Rice straw collected from previous season that contained approximately $17.5 \%$ moisture, $0.43 \%$ total nitrogen, $41 \%$ organic carbon with a $\mathrm{C}: \mathrm{N}$ ratio 95 and was applied at the rate of $5 \mathrm{t} \mathrm{ha}^{-1}$ to the selected plots 15 days before transplanting.

During the first year, the T. Aman rice was transplanted on 6 August, 2010 and Boro rice seedlings was transplanted on 15 January, 2011. In the second year of experimentation T. Aman rice was transplanted on 15 August, 2011 and Boro rice transplanted on 25 January 2012. Thirty days older seedlings were transplanted at $20 \mathrm{~cm} \times 20 \mathrm{~cm}$ spacing. The experimental field received $\mathrm{N}, \mathrm{P}, \mathrm{K}$ and $\mathrm{S}$ at the rates of 110,20 , 70 , and $15 \mathrm{~kg} \mathrm{ha}^{-1}$, respectively from urea, triple super phosphate (TSP), muriate of potash (MoP) and gypsum, respectively in aman, while these nutrients in boro were $180,27,120$ and $20 \mathrm{~kg}$ ha 1 , respectively according to BARC fertilizers recommendation model (BARC, 2005). The whole amount of TSP, MoP, gypsum were applied during final land preparation and urea was applied in three equal splits at 15 days after transplanting, at maximum vegetative stage and panicle initiation stage. Inter-culture operations were carried out as and when required. Proper irrigation practices were undertaken maintaining at least $5 \mathrm{~cm}$ water throughout the growing season. 


\subsection{Carbon dynamics and carbon dioxide emission}

Carbon dioxide emission was measured by $\mathrm{NaOH}$ absorption followed by $\mathrm{HCl}$ titration (Jain et al., 2003). Observation was taken by every 7 days interval and continued throughout the four crop growing seasons. $\mathrm{CO}_{2}$ traps were prepared using $80 \mathrm{ml}$ of $2 \mathrm{~N}-\mathrm{NaOH}$ into plastic bottles and placed in the plots under each treatment. Traps were covered with plastic buckets, which were inserted into soft mud to protect entrance of atmospheric $\mathrm{CO}_{2}$. An empty bucket was used as a control without soil but of alkali of same strength. After seven days of exposure, traps were removed from plots covering with screw cap and then titrated against $\mathrm{HCl}$. From $80 \mathrm{ml}$ of alkali solution, $2 \mathrm{ml}$ was titrated adding few drops of phenolphthalein indicator against $2 \mathrm{~N}$ $\mathrm{HCl}$. The amount of $\mathrm{CO}_{2}$ evolved from soil was calculated using the formula:

Milligrams of $\mathrm{C}$ or $\mathrm{CO}_{2}=(\mathrm{B}-\mathrm{V}) * \mathrm{~N} * \mathrm{E}$

where, $\mathrm{B}$ and $\mathrm{V}$ are volume $(\mathrm{ml})$ of acid needed to titrate trapped $\mathrm{NaOH}$ in the control and straw treated plots, respectively, $\mathrm{N}=$ normality of the acid, and $\mathrm{E}$ (equivalent weight) is either 6 or 12 to express data in terms of $\mathrm{C}$ or $\mathrm{CO}_{2}$, respectively. Data was expressed as $\mathrm{kg} \mathrm{CO}_{2} \mathrm{ha}^{-1}$ day $^{-1}$ soil and also as $\mathrm{kg} \mathrm{C} \mathrm{ha}^{-1} \mathrm{day}^{-1}$. Carbon degradation rate constant, $\mathrm{k}$ was calculated using the exponential kinetics, $\ln \left(\mathrm{C} / \mathrm{C}_{0}\right)=-\mathrm{kt}$, where, $\mathrm{C}$ and $\mathrm{C}_{0}$ are final and initial $\mathrm{C}$ contents, respectively; $\mathrm{t}$ is time in days (Avnimelech et al., 1984). Carbon build up was measured by subtracting initial soil $\mathrm{C}$ from residual soil $\mathrm{C}$ (Benbi and Senapati, 2010). Carbon balance was calculated at the end of the study period by using the following equation.

Carbon balance $=$ Input - Output

Input $=$ Inherent soil $\mathrm{C}+$ added $\mathrm{C}$ through rice straw before the four rice seasons + Rice straw C from straw and roots (remaining in the soil after first three rice seasons)

Residue rice straw and rice roots were quantified from a sample area of $1 \mathrm{~m}^{2}$ and then extrapolated to $\mathrm{kg} \mathrm{ha}^{-1}$. For collecting roots, a sample area was irrigated first to make soil soft and dig out from surrounding roots area and then roots were washed out, air dried and placed in an oven at $65^{\circ} \mathrm{C}$ for $48-72$ hours. Rice straw and roots were analyzed for carbon (Page et al., 1982).

Output $=\mathrm{C}$ emission + Residual $\mathrm{C}$ in the soil at the end of experiment after crop harvest

Initial and residual soil $\mathrm{C}$ was calculated in the $15 \mathrm{~cm}$ soil depth, by using the following equation.

Organic C $\left(\mathrm{kg} \mathrm{ha}^{-1}\right)=$ Conc. of soil $\mathrm{C}(\%) *$ soil bulk density $\left(\mathrm{g} \mathrm{cc}^{-1}\right) *$ soil depth $(\mathrm{cm}) * 1000$

\subsection{Analysis of soil physical characters}

Particle size distributions were done by hydrometer method (Black 1965). Bulk density and particle density of soils were determined by core sampler and Pycnometer method, respectively (Black, 1965). Soil porosity was computed from the relationship between bulk density (BD) and particle density (PD). Field capacity (FC) and permanent wilting point (PWP) were measured using pressure plate apparatus, where available water (d) was calculated using the equation given by Black (1965).

Porosity $(\%)=(1-\mathrm{BD} / \mathrm{PD}) \times 100$

$\mathrm{d}=($ FC-PWP $) / 100 * \mathrm{BD}\left(\mathrm{g} \mathrm{cc}^{-1}\right) *$ soil depth $(\mathrm{cm})$

\subsection{Statistical analysis}

SPSS version 12.0 statistical software (SPSS Inc., Chicago IL) was used to analyze the data. ANOVA and univariate analysis were performed and means were separated by LSD.

\section{Results and Discussion}

\subsection{Carbon dioxide emissions}

( $\mathrm{kg} \mathrm{CO} \mathrm{O}_{2} \mathrm{ha}^{-1} \mathrm{day}^{-1}$ )

Tillage operation did not show significant effect on $\mathrm{CO}_{2}$ emission from soil in T. Aman 2010 and Boro 2011, while TT released significantly higher amount of $\mathrm{CO}_{2}$ over MT in T. Aman 2011 
and Boro 2012 (Table 1). $\mathrm{CO}_{2}$ emission under MT were about 26, 34, 59 and $34 \mathrm{~kg} \mathrm{ha}^{-1} \mathrm{day}^{-1}$ in T. Aman 2010, Boro 2011, T. Aman 2011 and Boro 2012, respectively, while under TT, the respective values were $25,33,96$ and $65 \mathrm{~kg} \mathrm{ha}^{-1}$ day $^{-1}$. Rice straw management significantly affected $\mathrm{CO}_{2}$ emission from soil $(\mathrm{p}<0.05)$ in all four rice growing seasons (Table 1 ). In case of $\mathrm{T}$. Aman 2010, amount of $\mathrm{CO}_{2}$ released was significantly higher (36.61 kg CO $2 \mathrm{ha}^{-1}$ day $^{-1}$ ) in RSI over the RSM (27.33 kg CO ha $^{-1}$ day $\left.^{-1}\right)$. On the other hand, in case of Boro 2011, T. Aman 2011 and Boro 2012 straw application released significantly higher amount of $\mathrm{CO}_{2}$ over the control i.e. where no residues were added, but the amount of $\mathrm{CO}_{2}$ released from RSI and RSM were statistically similar. The interaction effect of tillage and rice straw was significant in $\mathrm{CO}_{2}$ emission under T. Aman 2010 (Table 2), while the interaction was non-significant in Boro 2011, T. Aman 2011 and Boro 2012 (Table 2 and 3). In case of T. Aman 2010, RSI in both tillage practices released significantly higher amount of $\mathrm{CO}_{2}$ from soil over other treatment combinations while RSI along with TT released the higher amounts of $37.4 \mathrm{~kg} \mathrm{CO}_{2} \mathrm{ha}^{-1} \mathrm{day}^{-1}$. It was found that in the entire four crop growing seasons the interactions of RSI and TT were contributed in higher $\mathrm{CO}_{2}$ emission from soil (Tables 2 and 3 ).

It was also noticed that in all the treatments of tillage verses rice straw management, emission of $\mathrm{CO}_{2}$ increased with the progress of crop growing period. At the beginning when carbon stock in soil was low, consequently carbon emission was also low. However, application of rice straw in each season and moreover residual amounts of carbon in soils accelerated microbial respiration and thus contributed to higher emission of $\mathrm{CO}_{2}$ in the latter stage of experiment. The higher amount of $\mathrm{CO}_{2}$ emission during $\mathrm{T}$. Aman 2011 (August to December) over Boro 2012 (January to May) might be attributed by faster microbial respiration because of higher air and soil temperatures in T. Aman season. The average air and soil temperatures during August to December were 23-30 and $27-31{ }^{0} \mathrm{C}$, respectively, while these values during January to May were $15-30$ and $20-28{ }^{\circ} \mathrm{C}$, respectively. Positive effect of air and soil temperatures on microbial decomposition and subsequent $\mathrm{CO}_{2}$ emission has been reported by other researchers (Grote and Al-Kaisi, 2007).

Table 1. Carbon dioxide emission $\left(\mathrm{kg} \mathrm{CO}_{2} \mathrm{ha}^{-1}\right.$ day $\left.^{-1}\right)$ under different tillage operations and rice straw management practices

\begin{tabular}{lcccc}
\hline \multicolumn{5}{c}{ Carbon dioxide emissions $\left(\mathrm{kg} \mathrm{CO}_{2} \mathrm{ha}^{-1}\right.$ day $\left.^{-1}\right)$} \\
\hline Tillage operation & T. Aman 10 & Boro 11 & T. Aman 11 & Boro 12 \\
\hline Minimum & 25.76 & 33.49 & $58.66 \mathrm{~b}$ & $33.92 \mathrm{~b}$ \\
Traditional & 25.28 & 33.46 & $95.75 \mathrm{a}$ & $64.77 \mathrm{a}$ \\
S.E. $( \pm)$ & 0.40 & 0.99 & 0.97 & 0.95 \\
\hline Rice straw management (5 t/ha) & & & & \\
\hline No rice straw & $12.63 \mathrm{c}$ & $14.54 \mathrm{~b}$ & $64.45 \mathrm{~b}$ & $37.12 \mathrm{~b}$ \\
Rice straw incorporation & $36.61 \mathrm{a}$ & $43.77 \mathrm{a}$ & $86.37 \mathrm{a}$ & $57.97 \mathrm{a}$ \\
Rice straw mulch & $27.33 \mathrm{~b}$ & $42.11 \mathrm{a}$ & $80.81 \mathrm{a}$ & $51.97 \mathrm{a}$ \\
S.E. $( \pm)$ & 0.48 & 1.22 & 1.19 & 1.17 \\
CV $(\%)$ & 5.36 & 10.23 & 4.36 & 6.69 \\
\hline Tillage practices x rice straw & $*$ & $\mathrm{NS}$ & $\mathrm{NS}$ & $\mathrm{NS}$ \\
\hline
\end{tabular}


Table 2. Interaction effects of tillage operations and rice straw management on $\mathrm{CO}_{2}$ emission $\left(\mathrm{kg} \mathrm{CO}_{2}\right.$ $\mathrm{ha}^{-1}$ day $^{-1}$ ) in Aman 2010 and Boro 2011

\begin{tabular}{lcccccc}
\hline \multirow{2}{*}{ Rice straw } & \multicolumn{6}{c}{ Carbon dioxide emissions $\left(\mathrm{kg} \mathrm{CO}_{2}\right.$ ha $^{-1}$ day $\left.^{-1}\right)$} \\
\cline { 2 - 7 } & MT & TT & $\begin{array}{c}\text { Difference } \\
\text { (TT-MT) }\end{array}$ & MT & TT & $\begin{array}{c}\text { Difference } \\
\text { (TT-MT) }\end{array}$ \\
\cline { 2 - 7 } & & & -0.02 & 15.34 & 13.75 & -1.59 \\
Control & $12.64 \mathrm{c}$ & $12.62 \mathrm{c}$ & 1.60 & 42.30 & 45.25 & 2.95 \\
RSI & $35.81 \mathrm{a}$ & $37.41 \mathrm{a}$ & -3.05 & 42.83 & 41.40 & -1.43 \\
RSM & $28.85 \mathrm{~b}$ & $25.80 \mathrm{~b}$ & \multicolumn{3}{c}{10.23} \\
\hline CV $(\%)$ & \multicolumn{3}{c}{5.36} & \multicolumn{5}{c}{} \\
\hline
\end{tabular}

$\mathrm{MT}=$ minimum tillage, $\mathrm{TT}=$ traditional tillage, $\mathrm{RSI}=$ rice straw incorporation,

$\mathrm{RSM}=$ rice straw mulch

Table 3. Interaction effects of tillage operations and rice straw management on $\mathrm{CO}_{2}$ emission $\left(\mathrm{kg} \mathrm{CO}_{2}\right.$ ha $^{-1}$ day $^{-1}$ ) in Aman 2011 and Boro 2012

\begin{tabular}{|c|c|c|c|c|c|c|}
\hline \multirow{3}{*}{ Rice straw } & \multicolumn{6}{|c|}{ Carbon dioxide emissions $\left(\mathrm{kg} \mathrm{CO}_{2}\right.$ ha $^{-1}$ day $\left.^{-1}\right)$} \\
\hline & \multicolumn{3}{|c|}{ Aman 2011} & \multicolumn{3}{|c|}{ Boro 2012} \\
\hline & MT & TT & $\begin{array}{l}\text { Difference } \\
\text { (TT-MT) }\end{array}$ & MT & TT & $\begin{array}{c}\text { Difference } \\
\text { (TT-MT) }\end{array}$ \\
\hline Control & 64.13 & 64.75 & 0.62 & 38.03 & 38.21 & 0.18 \\
\hline RSI & 83.72 & 89.01 & 5.29 & 56.22 & 59.71 & 3.49 \\
\hline RSM & 81.71 & 79.90 & -1.81 & 52.19 & 51.75 & -0.44 \\
\hline
\end{tabular}

$\mathrm{MT}=$ minimum tillage, $\mathrm{TT}=$ traditional tillage, $\mathrm{RSI}=$ rice straw incorporation,

$\mathrm{RSM}=$ rice straw mulch

There are some uncertainties associated with emission determination. Carbon dioxide emission in the rice field soils mainly depends on soil respiration and organic matter decomposition where soil temperature and moisture regimes amplify the process (Agehara and Warncke, 2005; Lee et al., 2006; IPCC, 2014). Temperature from plot to plot may vary and water depth in all plots could not be maintained at equal depths as flood irrigation was provided to rice fields. Because of the method used in the present study it was also not possible in partitioning total $\mathrm{CO}_{2}$ emission into microbial emission and root respiration. The diurnal variation also may cause as an uncertainty in measuring $\mathrm{CO}_{2}$. In the present study, $\mathrm{CO}_{2}$ was measured weekly from field at
$10.0 \mathrm{am}$ in the morning. Therefore, the uncertainties remained in our experiment and need to be addressed in future studies.

\subsection{Weekly released patterns of $\mathrm{CO}_{2}$ from soil}

In case of T. Aman 2010, during the first week $\mathrm{CO}_{2}$ emission rates showed a little difference among the tested treatments, being the lowest in MTC and the highest in MTRSM (Figure 1). The $\mathrm{CO}_{2}$ emission tended to increase in second week compared to the first week, but the magnitude of increase in case of MTRSM appeared noticeable. The trend of $\mathrm{CO}_{2}$ emission in the third week demonstrated a significant treatment interaction. The $\mathrm{CO}_{2}$ emission in TTRSM showed a consistent increasing trend up to third week, while it decreased in case of MTRSM and 
MTRSI compared to that of second week. Irrespective of the tillage treatment, the straw treated plots emitted the highest amount of $\mathrm{CO}_{2}$ in the fourth week but showed no difference among the method of straw incorporation and tillage operations. Contrast to the straw applied plots, $\mathrm{CO}_{2}$ evolution in the control treatment showed declining trend in fourth week and continued up to seventh week. The fifth week's evolution of $\mathrm{CO}_{2}$ declined in all the treatment negligible difference among them. $\mathrm{CO}_{2}$ evolution in the sixth week produced a second peak with the highest in TTRSI followed by MTRSM and MTRSI and the least in TTRSM. Receiving the straw mulching treatment both in TT and MT had lower $\mathrm{CO}_{2}$ emission than the rice straw incorporated one consistently during seventh to eleventh week. During twelfth to sixteenth weak of measurement, rice straw incorporation treatment emitted more $\mathrm{CO}_{2}$ compared to other treatment, but the treatment difference was not significant.
T. Aman 2010 was transplanted during the first week of August 2010 and the air temperature as well as soil temperatures were high at that time, which favored rapid microbial decomposition of added rice straw and therefore, $\mathrm{CO}_{2}$ emission was higher at that time. In the fifth week of rice growing period it was the first week of September 2010 when the air temperature decreased and also there was rainfall of about 8 mm (BSMRAU weather Office), which resulted in slower decomposition of organic residues and hence $\mathrm{CO}_{2}$ emission was low. However, though not measured under this study, methane emission under this flooded situation might have been higher. The maximum rates of $\mathrm{CO}_{2}$ emission were over $600 \mathrm{~kg} \mathrm{CO}_{2} \mathrm{ha}^{-1} \mathrm{wk}^{-1}$ found in all the treatments, except control (Figure 1). After twelve weeks of rice growing period, emission of $\mathrm{CO}_{2}$ decreased to 33 to $130 \mathrm{~kg} \mathrm{CO} \mathrm{ha}^{-1} \mathrm{wk}^{-1}$, which continued till the end of growing period.

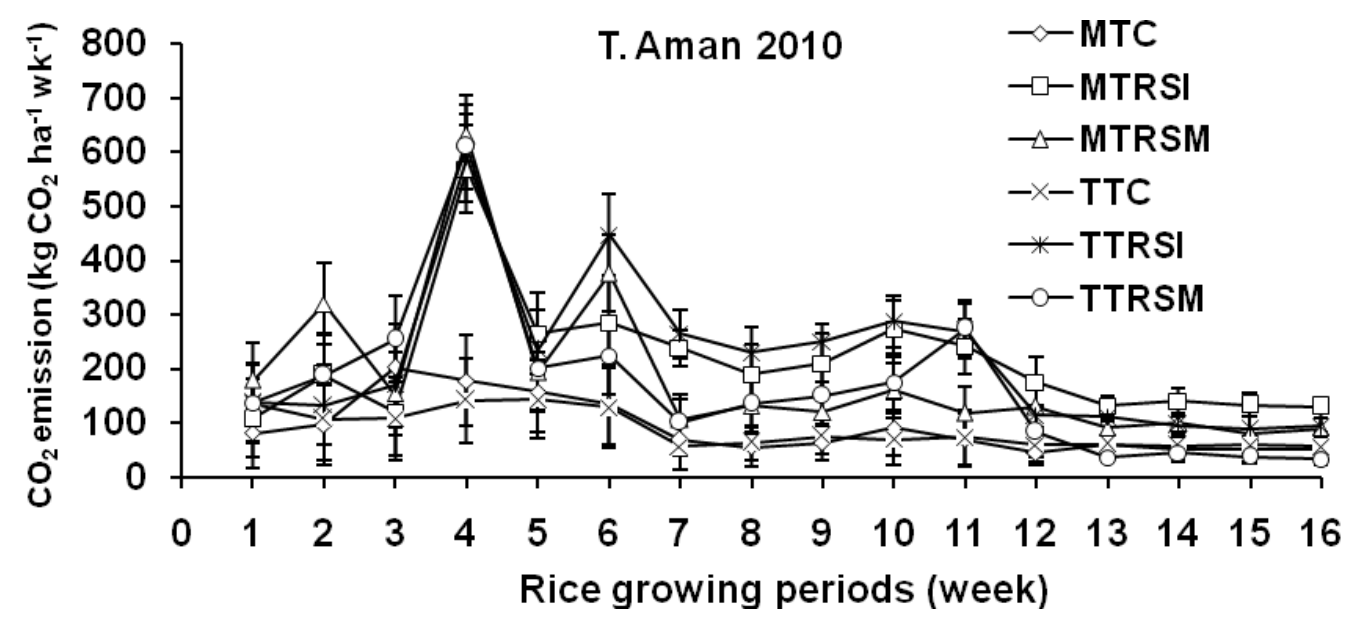

Figure 1. Carbon dioxide emissions ( $\mathrm{kg} \mathrm{CO}_{2} / \mathrm{ha} /$ week) under different tillage operations and rice straw management practices during T. aman 2010. MTC: minimum tillage control, MTRSI: minimum tillage rice straw incorporation, MTRSM: minimum tillage rice straw mulch, TTC: traditional tillage control, TTRSI: traditional tillage rice straw incorporation, TTRSM: traditional tillage rice straw mulch. 


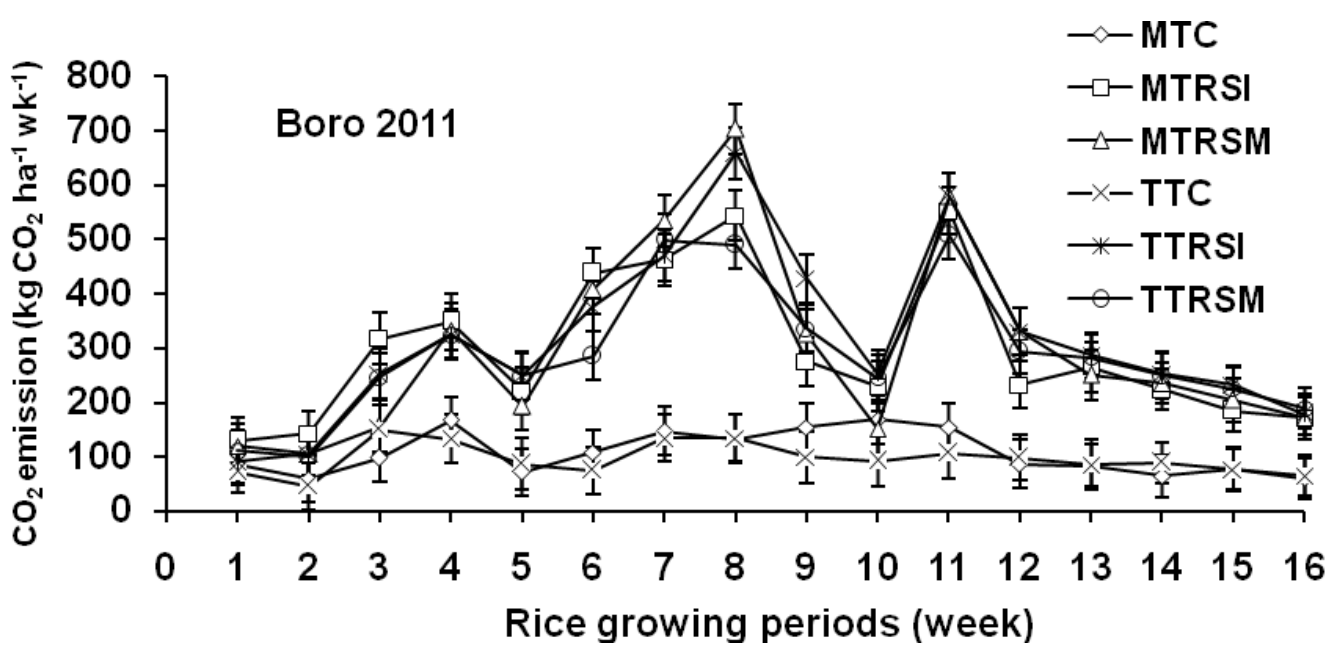

Figure 2. Carbon dioxide emission $\left(\mathrm{kg} \mathrm{CO}_{2} \mathrm{ha}^{-1} \mathrm{wk}^{-1}\right)$ measured under different tillage and rice straw management practices during boro 2011. MTC: minimum tillage control, MTRSI: minimum tillage rice straw incorporation, MTRSM: minimum tillage rice straw mulch, TTC: traditional tillage control, TTRSI: traditional tillage rice straw incorporation, TTRSM: traditional tillage rice straw mulch.

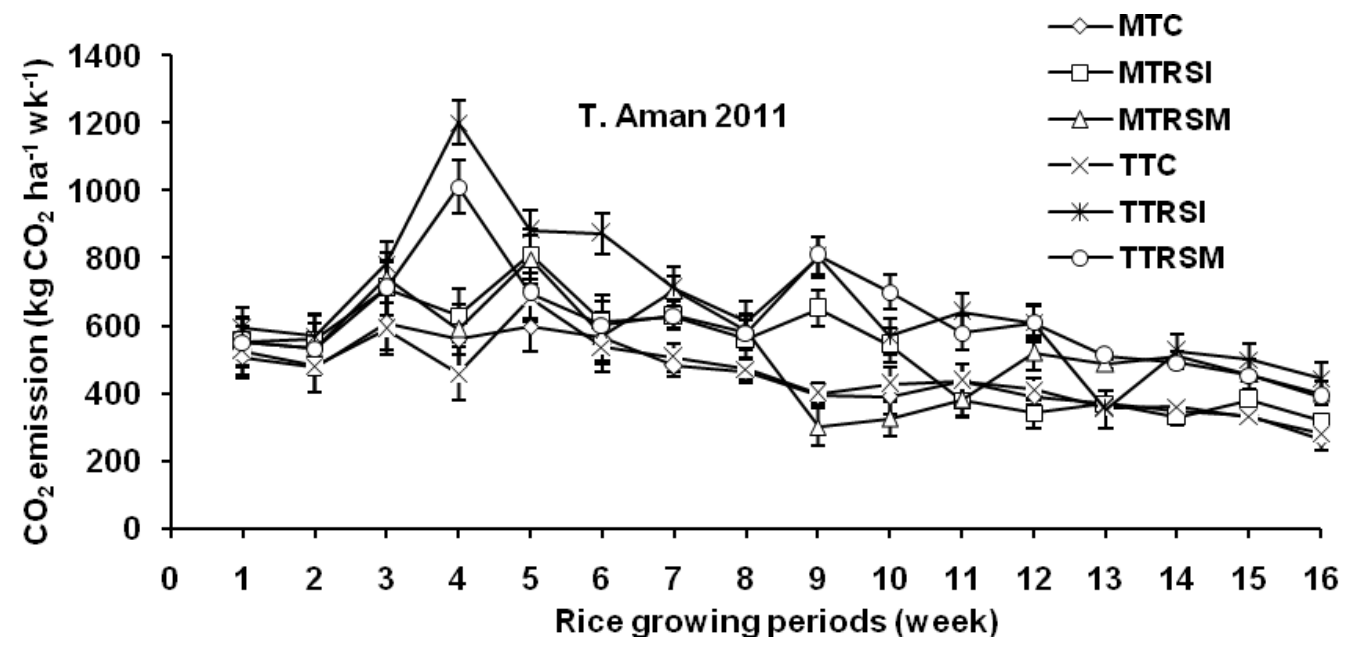

Figure 3. Carbon dioxide emission $\left(\mathrm{kg} \mathrm{CO}_{2} \mathrm{ha}^{-1} \mathrm{wk}^{-1}\right)$ measured under different tillage and rice straw management practices during T. aman 2012. MTC: minimum tillage control, MTRSI: minimum tillage rice straw incorporation, MTRSM: minimum tillage rice straw mulch, TTC: traditional tillage control, TTRSI: traditional tillage rice straw incorporation, TTRSM: traditional tillage rice straw mulch. 


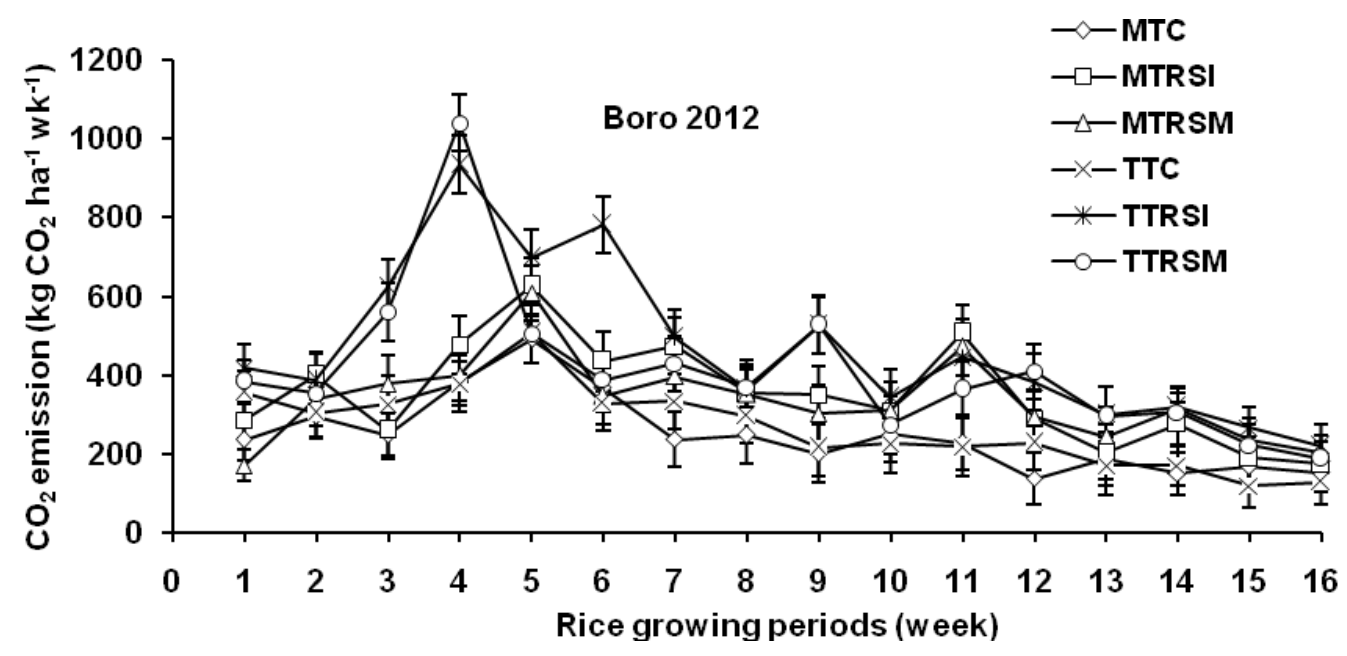

Figure 4. Carbon dioxide emission $\left(\mathrm{kg} \mathrm{CO}_{2} \mathrm{ha}^{-1} \mathrm{wk}^{-1}\right)$ measured under different tillage and rice straw management practices during boro 2012; MTC: minimum tillage control MTRSI: minimum tillage rice straw incorporation, MTRSM: minimum tillage rice straw mulch, TTC: traditional tillage control, TTRSI: traditional tillage rice straw incorporation, TTRSM: traditional tillage rice straw mulch.

In Boro 2011 (Figure 2), weekly released patterns of $\mathrm{CO}_{2}$ were different from that of $\mathrm{T}$. Aman 2010. During first two weeks $\mathrm{CO}_{2}$ emission rates showed a little difference among the tested treatments and remain almost same, while start increasing in the $3^{\text {rd }}$ week and drop down in the $5^{\text {th }}$ week then further increased and reached to a peak at the $8^{\text {th }}$ week of rice growing periods. Rice seedlings of Boro 2011 were transplanted on January 15, 2011 when temperatures were low, resulting in lower microbial activites. Emission of $\mathrm{CO}_{2}$ reached its peak at eight week of transplanting, when air temperature increased. The highest amount of $\mathrm{CO}_{2}$ released from straw mulched plot under MT were $703 \mathrm{~kg} \mathrm{CO}_{2} \mathrm{ha}^{-1} \mathrm{wk}^{-1}$. A second peak was observed at $11^{\text {th }}$ week of rice growing periods were MTRSM and TTRSI released the highest amount of $\mathrm{CO}_{2}$ which was $578 \mathrm{~kg} \mathrm{CO}_{2} \mathrm{ha}^{-1} \mathrm{wk}^{-1}$. After twelve weeks of rice growing periods emission of $\mathrm{CO}_{2}$ decreased to a range of 65-188 $\mathrm{kg} \mathrm{CO}_{2} \mathrm{ha}^{-1} \mathrm{wk}^{-1}$, which continued till the end of growing period. The release pattern of $\mathrm{CO}_{2}$ infers that degradation of carbon in soils is responding to increased soil and air temperatures. Under normal situation, the peak of $\mathrm{CO}_{2}$ emission reaches after 3-4 weeks of rice straw application in soil. In T. Aman 2011, $\mathrm{CO}_{2}$ emission slightly decreased in the $2^{\text {nd }}$ week, while start increasing in $3^{\text {rd }}$ week (Figure 3 ).

During $4^{\text {th }}$ week of rice growing periods emission increased and reached to the highest amount in TTRSI (1201 kg CO $\left.\mathrm{ha}^{-1} \mathrm{wk}^{-1}\right)$ and TTRM (1011 kg CO $\mathrm{ha}^{-1} \mathrm{wk}^{-1}$ ), while in all other treatment combinations $\mathrm{CO}_{2}$ emission decreased from the 3 rd week. Almost similar fashions in $\mathrm{CO}_{2}$ emission under different tested treatments were observed at $9^{\text {th }}$ week of growing season. At the end of $16^{\text {th }}$ week it reduced to 280 to $443 \mathrm{~kg}$ $\mathrm{CO}_{2} \mathrm{ha}^{-1} \mathrm{wk}^{-1}$. During Boro 2012 the emission of $\mathrm{CO}_{2}$ dropped down compared to both Boro and T. Aman 2011. The highest amount of $\mathrm{CO}_{2}$ released during Boro 2012 at $4^{\text {th }}$ week in TTRSM, which was $1039 \mathrm{~kg} \mathrm{CO}_{2} \mathrm{ha}^{-1} \mathrm{wk}^{-1}$ and in TTRSI, which was $932 \mathrm{~kg} \mathrm{CO} \mathrm{ha}^{-1} \mathrm{wk}^{-1}$, while in all other treatments emission decreased (Figure 4). At the end of $16^{\text {th }}$ week, it reduced to 
127 to $219 \mathrm{~kg} \mathrm{CO}_{2} \mathrm{ha}^{-1} \mathrm{wk}^{-1}$. It was found that trend of $\mathrm{CO}_{2}$ emission among four rice seasons of T. Aman and Boro varied widely. The probable reasons of seasonal variations of $\mathrm{CO}_{2}$ emission from soil treated with different organic materials are many where weather conditions, soil oxidation states and attributes of materials added are leading. The emission of $\mathrm{CO}_{2}$ from soil is an index of the activity of microorganisms which in most cases ranged from 25 to $40 \mathrm{~kg} \mathrm{ha}^{-1}$ day $^{-1}$ with a peak of about $100 \mathrm{~kg} \mathrm{ha}^{-1}$ day $^{-1}$ (Boyd 1995). Therefore, emission of $\mathrm{CO}_{2}$ in the present study is assumed to be somewhat higher which is attributed by subtropical climatic condition favoring faster microbial decomposition of soil organic matter. Emission of $\mathrm{CO}_{2}$ was reported higher in warmer weather which vary with soil $\mathrm{pH}$, moisture content, $\mathrm{O}_{2}$ supply and $\mathrm{N}$ availability as all these factors have profound effect on soil microbial dynamics and activity (Zebarth et al., 2009).

\subsection{Rice yield}

Tillage operations showed poor effect on grain yields of rice during four cropping seasons (Table 4). It needs longer time to get positive effect of MT in crop production and soil health improvement. However, the non-significant yield difference between tillage practices indicates the superiority of MT over TT. The effect of RSI and RSM on rice yield was found insignificant (Table 4). The maximum grain yields were observed 5.25 and $6.34 \mathrm{t} \mathrm{ha}^{-1}$ in T. Aman 2011 and Boro 2012, respectively.

However, the grain yields of rice in the present study were found satisfactory considering the national yield goals of BRRI dhan 49 and BRRI dhan29, which are 5.0 and $7.5 \mathrm{t} \mathrm{ha}^{-1}$, respectively set by BARC (2005). Incorporation of the crop stubble and straw into soil replenish nutrients and helps to conserve soil nutrient reserves in the long-term (Tuyen and Tan, 2001). Among different types of crop residues, rice straw is readily available in the wetland rice field, which can easily be incorporated into soil. It was observed that short-term effects of residue incorporation in soils on grain yield are often small, but in the long run it obviously would benefit significantly. Incorporation of rice straw improves soil health and fertility and thereby increases crop yields about $0.4 \mathrm{t} \mathrm{ha}^{-1}$ per season (Tuyen and Tan, 2001).

Table 4. Effect of tillage and rice straw on grain yields of T. Aman and Boro rice

\begin{tabular}{lcccc}
\hline \multicolumn{5}{c}{ Yield of rice grain at harvesting (t/ha) } \\
\hline Tillage operation: & T. Aman & Boro & T. Aman & Boro \\
\hline Minimum & 4.54 & 5.66 & 4.68 & 5.83 \\
Traditional & 4.50 & 5.74 & 4.92 & 6.05 \\
S.E. $( \pm)$ & 0.25 & 0.34 & 0.45 & 0.19 \\
\hline Rice straw management 5 t/ha): & & & & \\
\hline No rice straw & 3.90 & $4.90 \mathrm{~b}$ & $4.10 \mathrm{~b}$ & $5.21 \mathrm{~b}$ \\
Rice straw incorporation & 4.78 & $6.06 \mathrm{a}$ & $5.15 \mathrm{a}$ & $6.27 \mathrm{a}$ \\
Rice straw mulch & 4.89 & $6.13 \mathrm{a}$ & $5.25 \mathrm{a}$ & $6.34 \mathrm{a}$ \\
S.E. $( \pm)$ & 0.53 & 0.42 & 0.46 & 0.23 \\
CV $(\%)$ & 21.30 & 31.07 & 23.45 & 11.25 \\
Tillage practices x rice straw & $\mathrm{NS}$ & $\mathrm{NS}$ & $\mathrm{NS}$ & $\mathrm{NS}$ \\
\hline
\end{tabular}


In the present study, seasonal and year to year variations in grain yields of T. Aman and Boro rice were also observed. Because of better soil, water and crop management practices grain yields of both Aman and Boro rice increased positively from the year 2010 to 2012 . Yield of Boro rice was higher than that of Aman rice owing to higher yield potential and more photosynthetically active radiation in the Boro season. The average yield of modern rice varieties is 1.0 to $1.5 \mathrm{t} \mathrm{ha}^{-1}$ higher in the Boro season compared to the Aman season due to favorable growing environment such as high sun shine hour and low pest pressure (Hossain et al., 2013).

\subsection{Soil chemical properties}

Tillage operation significantly influenced soil available $\mathrm{S}$ and exchangeable $\mathrm{K}$, while its effect was non-significant in case of $\mathrm{pH}, \mathrm{OC}$, total $\mathrm{N}$, available $\mathrm{P}$, available $\mathrm{Zn}$ and $\mathrm{B}$ (Table 5). The significantly higher amounts of $\mathrm{K}$ and $\mathrm{S}$ were found in soils under MT having the values 0.17 $\mathrm{cmol} \mathrm{kg}^{-1}$ and $7.22 \mathrm{mg} \mathrm{kg}^{-1}$, respectively, while under TT the values were $0.16 \mathrm{cmol} \mathrm{kg}^{-1}$ and $5.81 \mathrm{mg} \mathrm{kg}^{-1}$, respectively. Soil chemical properties were significantly influenced by rice straw application over the control (Table 5). However, non-significant differences in soil nutrients including $\mathrm{pH}$, were noticed between rice straw incorporation and mulch treatments.

Plants can alter soil $\mathrm{pH}$ by releasing root exudates, such as organic acids and anions, to enhance mineral nutrient solubility as well as liberation of $\mathrm{OH}^{-}$or $\mathrm{HCO}_{3}{ }^{-}$resulting from $\mathrm{OH}^{-}$ carbonation in order to counter balance cations entering the roots (Hinsinger, 2003). Decomposition of organic acid anions can also increase soil $\mathrm{pH}$ due to proton consumption in the decarboxylation process. Organic matter from residues improved soil $\mathrm{pH}$ status by increasing buffering capacity (Ogbodo, 2011). Mineralization of rice straw might contribute to soil total $\mathrm{N}$, available $\mathrm{P}, \mathrm{S}, \mathrm{Zn}, \mathrm{B}$ and exchangeable $\mathrm{K}$. Rice straw applied to soils acted as a harbor of microbes as well OM contents in soil is increased, which enriches the labile pool of nutrients. Improvement of soil $\mathrm{pH}$ led to solubilzation of inorganic $\mathrm{P}$ (Ogbodo, 2011). Rice straw contains higher amount of potassium, therefore, $\mathrm{K}$ concentration was expectedly higher under straw treatment. The hydrogen ions released from organic materials are exchanged with $\mathrm{K}$ on exchange site or set free from the fixed site of the clay micelle. Thus, the overall status of soil regarding availability of potassium is improved (Singh et al., 2002).

\subsection{Carbon balance}

The effect of tillage practices and rice straw incorporation were found significant on cumulative emission of carbon in all the four rice growing seasons (Table 6). Traditional tillage and rice straw application (either mulch or incorporation) released higher amount of carbon compared to MT and control, respectively. It is worthy to note that total carbon input under TT was higher by about $1000 \mathrm{~kg} \mathrm{ha}^{-1}$ over MT, which might have significant positive effect on higher emission of carbon from soil. Residual carbon in soils revealed the opposite trends to carbon emission i.e. carbon accumulation in soil was found higher under MT. Rice straw mulch and RSI did not show significant difference in carbon accumulation in soils.

Carbon balance was significantly affected by rice straw application. Carbon balance may be positive, negative or even zero depending on the nature and types of carbon source applied in soil, presence of microbial communities, soil physical and chemical properties and agronomic management practices. The positive carbon balance (input>output) indicates some amount of inputs could not be traced out in soil system, while negative balance (input<output) indicates addition of carbon over the applied amount due to higher microbial activities. Carbon cycling is the continuous transformation of organic and inorganic carbon compounds by plants and micro- and macro-organisms between soil, plants and atmosphere. In cultivated organic soils, about $450-4500 \mathrm{~kg}$ bacteria are present in the furrow slice, while fungi ranges in 1120-11200 $\mathrm{kg} / \mathrm{ha}$ and actinomycetes ranges in 450- 4500 
$\mathrm{kg} / \mathrm{ha}$ (Brady, 2001). Bacteria, fungi and actinomycetes are 50\% carbon (Boyd, 1995). Thus a significant amount of carbon might be added to soils.

Carbon degradation rate constant, $\mathrm{k}$ was found significantly higher under TT than MT, while carbon build up was higher in MT (Table 6). Rice straw mulching or incorporation did not show significant difference on $\mathrm{C}$ emission, degradation and build up. The $\mathrm{k}$ value in the present study under the MT was $0.000300 \mathrm{~d}^{-1}$, while it was $0.000394 \mathrm{~d}^{-1}$ under TT. Rahman (2013b) reported from a laboratory study that carbon degradation rate constants $(\mathrm{k})$ of rice straw varied from 0.002834 to $0.005104 \mathrm{~d}^{-1}$. Jorgensen (1979) found $\mathrm{k}$ value of 0.00001 to $0.0008 \mathrm{~d}^{-1}$ for mineral soil. Significantly lower C emission and degradation rate, $\mathrm{k}$ in soils attributed higher $\mathrm{C}$ build up under MT than TT. Under MT and TT carbon build up were 3813 and $1980 \mathrm{~kg} \mathrm{ha}^{-1}$, respectively. Variation in carbon build up in soil from different manures and crop residues depends on their application rates and carbon contents. During ten years of rice cropping Bhattaacharyya et al. (2012) found that application of rice straw at the rate of $7.12 \mathrm{t}$ $\mathrm{ha}^{-1} \mathrm{yr}^{-1}$ carbon content in soil was increased by $1230 \mathrm{~kg} \mathrm{C} \mathrm{ha}{ }^{-1}$, while rice straw applied at the rate of $4.8 \mathrm{t} \mathrm{ha}^{-1} \mathrm{yr}^{-1}$ along with inorganic fertilizes contributed to $1390 \mathrm{~kg} \mathrm{C} \mathrm{ha}^{-1}$. Rahman et al. (2016) applied rice straw at the rate of $2 \mathrm{t} \mathrm{C}$ $\mathrm{ha}^{-1}$ season $^{-1}$ in five consecutive rice growing season and found that carbon content increased by $1040 \mathrm{~kg} \mathrm{C} \mathrm{ha}^{-1}$. In the present study, initial carbon concentration in soil under MT was $1.18 \%$, while in residual soil it was increased to $1.37 \%$ i.e. the carbon increment was only $0.19 \%$ after four consecutive rice growing season taking all carbon inputs viz. initial soil carbon, carbon applied as rice straw, residual rice straw and rice roots. On the other hand, carbon increment under TT practice was only $0.09 \%$. Though the carbon increment in soil was found small, however, it has immense positive effect in reducing $\mathrm{CO}_{2}$ concentration in the atmosphere over the longer term, which would help in mitigating global warming and climate change.

Table 5. Effect of tillage practices and rice straw management on soil fertility statuses after harvest fourth crop (Boro 2012)

\begin{tabular}{|c|c|c|c|c|c|c|c|c|}
\hline \multirow[b]{2}{*}{ Treatment } & \multicolumn{8}{|c|}{ Soil chemical properties } \\
\hline & $\mathrm{pH}$ & $\begin{array}{c}\text { Carbon } \\
(\%)\end{array}$ & $\begin{array}{c}\text { Total } \\
\mathrm{N} \\
(\%)\end{array}$ & $\begin{array}{c}\text { Available } \\
\mathrm{P} \\
\left(\mathrm{mg} \mathrm{kg}^{-1}\right)\end{array}$ & $\begin{array}{c}\text { Exchangeable } \\
\mathrm{K} \\
\left(\mathrm{cmol} \mathrm{kg}^{-1}\right)\end{array}$ & $\begin{array}{c}\text { Available } \\
\mathrm{S} \\
\left(\mathrm{mg} \mathrm{kg}^{-1}\right)\end{array}$ & $\begin{array}{l}\text { Available } \\
\text { Zn } \\
\left(\mathrm{mg} \mathrm{kg}^{-1}\right)\end{array}$ & $\begin{array}{c}\text { Available } \\
\text { B } \\
\left(\mathrm{mg} \mathrm{kg}^{-1}\right)\end{array}$ \\
\hline \multicolumn{9}{|l|}{ Tillage } \\
\hline Minimum & 5.7 & 1.37 & 0.10 & 2.10 & $0.17 \mathrm{a}$ & $7.22 \mathrm{a}$ & 2.46 & 0.25 \\
\hline Traditional & 5.6 & 1.32 & 0.10 & 1.94 & $0.16 b$ & $5.81 b$ & 2.40 & 0.26 \\
\hline$S E( \pm)$ & 0.094 & 0.05 & 0.010 & 0.232 & 0.002 & 0.438 & 0.107 & 0.014 \\
\hline \multicolumn{9}{|c|}{ Rice straw (5t/ha) } \\
\hline No rice straw & $5.4 \mathrm{~b}$ & $1.17 \mathrm{~b}$ & $0.07 b$ & $1.57 \mathrm{~b}$ & $0.15 b$ & $5.31 b$ & 2.31 & $0.22 b$ \\
\hline $\begin{array}{l}\text { Rice straw } \\
\text { incorporation }\end{array}$ & $5.8 \mathrm{a}$ & $1.36 \mathrm{a}$ & $0.13 a$ & $2.43 \mathrm{a}$ & $0.18 \mathrm{a}$ & $7.73 a$ & 2.58 & $0.28 \mathrm{a}$ \\
\hline $\begin{array}{l}\text { Rice straw } \\
\text { mulch }\end{array}$ & $5.7 \mathrm{a}$ & $1.37 \mathrm{a}$ & $0.11 \mathrm{a}$ & $2.06 a b$ & $0.17 \mathrm{a}$ & $6.50 \mathrm{a}$ & 2.41 & $0.27 \mathrm{a}$ \\
\hline $\begin{array}{l}S E( \pm) \\
C V(\%)\end{array}$ & $\begin{array}{l}0.116 \\
4.14\end{array}$ & $\begin{array}{l}0.45 \\
13.47\end{array}$ & $\begin{array}{l}0.012 \\
24.95\end{array}$ & $\begin{array}{l}0.284 \\
28.15\end{array}$ & $\begin{array}{l}0.003 \\
5.87\end{array}$ & $\begin{array}{l}0.537 \\
16.49\end{array}$ & $\begin{array}{l}0.131 \\
10.82\end{array}$ & $\begin{array}{l}0.017 \\
13.91\end{array}$ \\
\hline $\begin{array}{l}\text { Tillage } x \\
\text { Rice straw }\end{array}$ & NS & NS & NS & NS & NS & NS & NS & NS \\
\hline
\end{tabular}


Table 6. Carbon input-output balance, degradation rate constant and carbon build up

\begin{tabular}{|c|c|c|c|c|c|c|c|c|c|c|c|}
\hline \multirow{2}{*}{$\begin{array}{l}\text { Treatment } \\
\text { factors }\end{array}$} & \multicolumn{5}{|c|}{$\mathrm{C}$ input $\left(\mathrm{kg} \mathrm{ha}^{-1}\right)$} & \multicolumn{3}{|c|}{ C output $\left(\mathrm{kg} \mathrm{ha}^{-1}\right)$} & \multirow{2}{*}{ Balance } & \multirow{2}{*}{$\mathrm{k}\left(\mathrm{d}^{-1}\right)$} & \multirow{2}{*}{$\begin{array}{c}\text { C build } \\
\text { up } \\
\left(\mathrm{kg} \mathrm{ha}^{-1}\right)\end{array}$} \\
\hline & ICS & RS1 & RS2 & RR & Total & Emission & Residual & Total & & & \\
\hline \multicolumn{12}{|l|}{ Tillage: } \\
\hline Minimum & 23563 & 4800 & 1361 & 1983 & 31706 & $4638 b$ & $27376 a$ & 32015 & -309 & $0.000300 \mathrm{~b}$ & $3813 a$ \\
\hline Traditiona & 24340 & 4800 & 1378 & 2130 & 32647 & $6697 \mathrm{a}$ & $26320 \mathrm{~b}$ & 33017 & -370 & $0.000394 \mathrm{a}$ & $1980 \mathrm{~b}$ \\
\hline$S E( \pm)$ & 498 & 00 & 19 & 55 & 479 & 67 & 539 & 48 & 332 & - & 320 \\
\hline \multicolumn{12}{|l|}{ RS (5 t/ha): } \\
\hline$\overline{\text { Control }}$ & 22367 & 00 & 909 & 1541 & 24816 & $3963 b$ & $23723 b$ & 27686 & $-2869 \mathrm{c}$ & $0.000241 b$ & $1356 \mathrm{~b}$ \\
\hline RS & 24880 & 7200 & 1600 & 2431 & 36112 & $6864 a$ & $28816 \mathrm{a}$ & 35679 & $433 b$ & $0.000404 \mathrm{a}$ & $3935 a$ \\
\hline RS mulch & 24605 & 7200 & 1600 & 2196 & 35601 & $6177 \mathrm{a}$ & $28005 \mathrm{a}$ & 34182 & $1419 a$ & $0.000372 \mathrm{a}$ & $3400 \mathrm{a}$ \\
\hline$S E( \pm)$ & 610 & 00 & 24 & 67 & 586.9 & 83 & 660 & 671 & 406 & - & 392 \\
\hline
\end{tabular}

ICS = initial carbon in soil, RS1 = rice straw added carbon, RS2 = residue rice straw carbon, RS = rice straw, RR $=$ rice root carbon, $\mathrm{C}=$ carbon, $\mathrm{k}=$ degradation rate constant

\subsection{Soil physical properties}

Tillage practices showed significant effect on soil bulk density and field capacity, whereas insignificant effect was observed in soil particle density, porosity, permanent wilting point and available water content (Table 7). On the other hand, rice straw application showed significant effects on soil bulk density, field capacity, permanent wilting point and available water content, while insignificant effect was noticed in case of soil particle density and porosity (Table 7). Soil bulk density was higher under MT $\left(1.35 \mathrm{~g} \mathrm{~cm}^{-3}\right)$ than that of TT $\left(1.33 \mathrm{~g} \mathrm{~cm}^{-3}\right)$, field capacity was higher in TT $(27.12 \%)$ compared to MT $(24.5 \%)$. These findings are in agreement with the studies of Husnjak et al. (2002). It is fact that the particle density not altered easily by normal physical manipulation of soil.

The soil porosity ranged from 45.88 to $47.88 \%$. The lowest soil porosity $45.88 \%$ was recorded where no rice straw was added. Comparatively lower porosity was also found in MT than that of TT. Soil porosity is very much influenced by the soil bulk density as particle density is not greatly altered by the agricultural manipulation. Rice straw application and intensive ploughing made the soil more aggregated and porous. The bulk density of initial soil was $1.38 \mathrm{~g} \mathrm{~cm}^{-3}$, which decreased to $1.33 \mathrm{~g} \mathrm{~cm}^{-3}$ where rice straw was incorporated and $1.31 \mathrm{~g} \mathrm{~cm}^{-3}$ where more tillage was done, which indicated that addition of rice straw and TT made surface soil loose and porous, thus enhanced the capacity of soil to store and retain more moisture. Therefore, the field capacity of surface soil was increased in such condition. The lowest field capacity $(23.10 \%)$ was recorded in soils where rice straw was not applied. The highest field capacity of $27 \%$ was recorded under TT and also rice straw applied treatment.

The permanent wilting point and available water contents were found significantly higher under rice straw applied soils over the control treatment (Table 7). In rice-rice cropping systems repeated adoption of traditional tillage increases micropores that can hold more water. On the other hand, organic matter contents under rice straw applied plots were found significantly higher compared to the control (Table 5), which might be the reason of increased moisture holding at permanent wilting point. Organic matter addition improves soil structure and increase water holding capacity of soil. Torkashvand and Shadparvar (2013) reported that application of rice straw and municipal waste significantly increased field capacity, permanent wilting point and plant available water content in soil. 
Table 7. Effect of tillage practices and rice straw management on soil physical properties at $0-15 \mathrm{~cm}$ soil depth of post experimental soil after four rice crop

\begin{tabular}{lcccccc}
\hline Treatments & \multicolumn{5}{c}{ Soil physical properties } \\
\cline { 2 - 6 } & $\begin{array}{c}\text { Bulk } \\
\text { density } \\
\left(\mathrm{g} \mathrm{cm}^{-3}\right)\end{array}$ & $\begin{array}{c}\text { Particle } \\
\text { density } \\
\left(\mathrm{g} \mathrm{cm}^{-3}\right)\end{array}$ & $\begin{array}{c}\text { Porosity } \\
(\%)\end{array}$ & $\begin{array}{c}\text { Field } \\
\text { capacity } \\
(\%)\end{array}$ & $\begin{array}{c}\text { Permanent } \\
\text { wilting point } \\
(\%)\end{array}$ & $\begin{array}{c}\text { Available water } \\
\text { content } \\
\text { (cm of water in } \\
\text { the upper layer) }\end{array}$ \\
\hline Tillage: & & & & & \\
\hline $\begin{array}{l}\text { Minimum } \\
\text { tillage }\end{array}$ & $1.35 \mathrm{a}$ & 2.53 & 46.64 & $24.50 \mathrm{~b}$ & 10.44 & 2.85 \\
$\begin{array}{l}\text { Traditional } \\
\text { tillage }\end{array}$ & $1.31 \mathrm{~b}$ & 2.51 & 47.80 & $27.12 \mathrm{a}$ & 12.12 & 2.95 \\
$\begin{array}{l}S E( \pm) \\
\text { Rice straw (5 t/ha) }\end{array}$ & 0.014 & 0.007 & 0.512 & 1.012 & 0.753 & 0.101 \\
\hline $\begin{array}{l}\text { No rice straw } \\
\text { Rice straw }\end{array}$ & $1.38 \mathrm{a}$ & 2.55 & 45.88 & $23.10 \mathrm{~b}$ & $10.10 \mathrm{~b}$ & $2.69 \mathrm{~b}$ \\
$\begin{array}{l}\text { incorporation } \\
\text { Rice straw } \\
\text { mulch }\end{array}$ & $1.33 \mathrm{~b}$ & 2.54 & 47.64 & $27.53 \mathrm{a}$ & $11.53 \mathrm{ab}$ & $3.19 \mathrm{a}$ \\
$\begin{array}{l}S E( \pm) \\
C V(\%)\end{array}$ & $1.36 \mathrm{a}$ & 2.54 & 46.46 & $27.22 \mathrm{a}$ & $12.10 \mathrm{a}$ & $3.08 \mathrm{a}$ \\
\hline
\end{tabular}

Therefore, from our study it can be accentuated that manipulation of soil moisture dynamics through tillage and rice straw management could be one of the feasible ways of higher moisture retention and increased crop production.

\section{Conclusions}

Minimum tillage was found positive in soil carbon enrichment and $\mathrm{CO}_{2}$ emission reduction. Emission of $\mathrm{CO}_{2}$ under minimum tillage were 26, 34, 59 and $34 \mathrm{~kg} \mathrm{ha}^{-1} \mathrm{day}^{-1}$ in T. Aman 2010, Boro 2011, T. Aman 2011 and Boro 2012, respectively, while under traditional tillage respective values were $25,33,96$ and $65 \mathrm{~kg} \mathrm{ha}^{-1}$ day ${ }^{-1}$. During the entire four rice growing seasons the interactions of RSI and TT were contributed in higher $\mathrm{CO}_{2}$ emission from soil. In most of the cases the peak values of $\mathrm{CO}_{2}$ emission reached after 3-4 weeks of straw application, irrespective of tillage practices. Rice straw mulching or incorporation did not show significant difference on $\mathrm{C}$ emission, degradation and build up in soil. Carbon degradation rate constant $(\mathrm{k})$ and $\mathrm{C}$ build up under minimum tillage were $0.0003\left(\right.$ day $\left.^{-1}\right)$ and $3.8 \mathrm{t} \mathrm{ha}^{-1}$, respectively, while in traditional tillage respective values were $0.000394\left(\right.$ day $\left.^{-1}\right)$ and $1.9 \mathrm{t} \mathrm{ha}^{-1}$. Slow degradation of rice straw ensures an uninterrupted supply of soil nutrients and thereby improves soil fertility. After four consecutive rice seasons, the increment in soil C was found small, however, which may exert immense positive effect in reducing $\mathrm{CO}_{2}$ emission in the atmosphere on the long term basis and thus helping in mitigating global warming and climate change.

\section{Acknowledgement}

The research was conducted under the 'Carbon sequestration in soils of Bangladesh' project (ID \# 305) of National Agricultural Technology Program (NATP), Phase 1 of Bangladesh Agricultural Research Council, Dhaka 1215, Bangladesh and Modeling Climate Change Impact in Agriculture of Bangladesh project of Krishi Gobeshona Foundation (KGF). 


\section{References}

Agehara, S. and Warncke, D. D. 2005. Soil alternate wetting and dryingure and temperature effects on nitrogen release from organic nitrogen sources. Soil Science Society of America Journal, 69: 1844-1855.

Avnimelech, Y., McHenry, J. R. and Ross, D. D. 1984. Decomposition of organic matter in lake sediments. Environmental Science and Technology, 18: 5-11.

BARC. 2005. Fertilizer recommendation guide, Bangladesh Agricultural Research Council (BARC), Farmgate, Dhaka, Bangladesh, $260 \mathrm{p}$.

Benbi, D. K. and Senapati, N. 2010. Soil aggregation and carbon and nitrogen stabilization in relation to residues and manure application in rice-wheat systems in northwest India. Nutrient Cycling in Agroecosystems, 87: 233-247.

Bhattaacharyya, P., Roy, K. S., Neogi, S., Chakravorti, S. P., Behera, K. S., Das, K. M., Bardhan, S. and Rao, K. S. 2012. Effect of long-term application of organic amendment on $\mathrm{C}$ storage in relation to global warming potential and biological activities in tropical flooded soil planted to rice. Nutrient Cycling in Agroecosystems, 94: 273-285.

Black, C. A. 1965. Method of soil analysis Part I and II. Amer. Soc. Agron. Inc. Madison, Wiscosin, USA, $770 \mathrm{p}$.

Boyd, C. E. 1995. Bottom soils, sediment and pond aquaculture. Chapman \& Hall, New York.

Brady, N. C. 2001. The nature and properties of soils. Prentice-Hall of India Private Ltd.

Brammer, H. 1978. Soils and Rice. The International Rice Research Institute, Manila, Philippines, 35-55 pp.
Eve, M. D, Sperow, M., Howerton, K., Paustian, K. and Follet, R. F. 2002. Predicted impact of management changes on soil carbon stocks for each agricultural region of the conterminous United States. Journal of Soil and Water Conservation, 57: 196-204.

Grote, J. B. and Al-Kaisi, M. M. 2007. Topsoil placement effect on soil carbon stock improvement of exposed subsoil in Iowa. Journal of Soil and Water Conservation, 62(2): 86-93.

Hinsinger, P. 2003. Origins of root-mediated $\mathrm{pH}$ changes in the rhizosphere and their responses to environmental constraints: a review. Plant and Soil, 248: 43-50.

Hossain, M., Jaim, W. M. H., Alam, M. S. and Rahman, A. N. M. M. 2013. Rice biodiversity in Bangladesh: adoption, diffusion and disappearance of varieties. BRAC Research and Evaluation Division, Dhaka, Bangladesh, 118 p.

Husnjak, S., Filipovic, D. and Kosutic, S. 2002. Influence of different tillage systems on soil properties and crop yield. Rostlinná Výroba, 48: 249-254.

IPCC. 2000. Land use, land-use change, and forestry special report. Cambridge University Press, 377 p.

IPCC. 2014. Climate change 2014: mitigation of climate change. Contribution of Working Group III to the Fifth Assessment Report of the Intergovernmental Panel on Climate Change. Cambridge University Press, 1207 p.

Jain, M. C., Pathak, H. and Bhatia, A. 2003. Measurement of greenhouse emission from soil and developing emission inventories. In H. Pathak \& S. Kumer (Eds.), Soil and greenhouse effect monitoring and evaluation, CBS Publishers and Distributors, New Delhi, India, 65-78 pp. 
Jorgensen, S. E. 1979. Handbook of environmental data and ecological parameters. Pergamon Press, Oxford.

Lee, J., Six, J., King, A. P., van Kessel, C. and Rolston, D. 2006. Tillage and field scale controls on greenhouse gas emission. Journal of Environmental Quality, 35: 714-725.

Munoz, C., Paulino, L., Monreal, C. and Zagal, E. 2010. Grenhouse gas $\left(\mathrm{CO}_{2}\right.$ and $\left.\mathrm{N}_{2} \mathrm{O}\right)$ emission from soils: a review. Chilean Journal of Agricultural Research, 70: 485- 497.

Ogbodo, E. N. 2011. Effect of crop residue on soil chemical properties and rice yield on an Ultisol at Abakaliki, Southeastern Nigeria. World Journal of Agricultural Science, 7: 13-18.

Page, A. L., Miller, R. H. and Kuny, D. R. 1982. Methods of Soil Analysis. Part 2. chemical and microbiological properties, $2^{\text {nd }}$ edn., American Society of Agronomy, Inc., Soil Science Society of American Inc. Madison, Wisconsin, USA. 403-430 pp.

Rahman, M. M. 2010. Carbon build up options in soils under different crops and their management practices. The Agriculturists, 8: $90-101$.

Rahman, M. M. 2013a. Carbon dioxide emission from soil. Agricultural Research, 2:132139.
Rahman, M. M. 2013b. Nutrient use and carbon build up efficiencies in soils from different organic wastes in rice and tomato cultivation. Communication in Soil Science and Plant Analysis, 44: 14571471.

Rahman, F., Rahman, M. M., Rahman, G. K. M. M., Saleque, M. A., Hossain, A. T. M. S. and Miah, G. (2016). Effect of organic and inorganic fertilizers and rice straw on carbon sequestration and soil fertility under a rice-rice cropping pattern. Carbon Management, 7(1-2):41-53.

Singh, S., Singh, R. N., Prasad, J. and Kumar, B. 2002. Effect of green manuring, FYM and bio-fertilizer in relation to fertilizer nitrogen on yield and major nutrient uptake by upland rice. Journal of Indian Society of Soil Science, 50: 313-314.

Torkashvand, A. M. and Shadparvar, V. 2013. Effect of some organic waste and zeolite on water holding capacity and PWP delay of soil. Current Biotica, 6(4): 459-465.

Tuyen, T. Q. and Tan, P. S. 2001. Effects of straw management, tillage practices on soil fertility and grain yield of rice. Omonrice, 9: 74-78.

Zebarth, B. J., Dury, C. F., Tremlay, N., and Cambouris, A. N. 2009. Opportunities for improved fertilizer nitrogen management in production of arable crops in eastern Canada: A review. Canadian Journal of Soil Science, 89: 113-132. 